\title{
THE TREATMENT OF TETANUS BY ANTITETANIC SERUM *
}

AN ANALYSIS OF 225 CASES, 1907-1913

ERNEST E. IRONS

(From the Memorial Institute for Infectious Diseases, Chicago.)

The mortality of tetanus treated symptomatically is estimated by most observers at from 78 to 90 percent. A few authors have given figures considerably lower than this, but these latter vary so greatly from the average that it seems that the apparent reduction in mortality must have been due to some unrecognized factor of selection in the compilation of statistics.

TABLE 1

Mortality of Tetanus Without Serum

(Hospital Statistics Collected by Permin)

\begin{tabular}{|c|c|c|c|}
\hline Larrey & $\begin{array}{l}\text { Percent } \\
82.5\end{array}$ & Fricker & $\begin{array}{l}\text { Percent } \\
88.8\end{array}$ \\
\hline Poland & 86.0 & Posselt ....... & 80.0 \\
\hline American Civil War ........ & 89.3 & Faber & 82.5 \\
\hline Richter $\ldots \ldots \ldots \ldots \ldots \ldots \ldots$ & 88.0 & $\ldots \ldots \ldots \ldots \ldots$ & 44.0 \\
\hline $\begin{array}{l}\text { Demme } \ldots \ldots \ldots \ldots \ldots \ldots \ldots \ldots \ldots \\
\text { Rose } \ldots \ldots \ldots \ldots \ldots \ldots \ldots \ldots \ldots \ldots\end{array}$ & $\begin{array}{l}85.7 \\
78.0\end{array}$ & Kowalski $\ldots \ldots \ldots \ldots \ldots \ldots$ & 34.9 \\
\hline
\end{tabular}

A number of factors combine to influence the prognosis of the individual case.

Tetanus is commonly divided into acute and chronic, accorfling to whether the interval between the injury and first appearance of symptoms is eight to ten days or less, or more than ten days. This arbitrary division affords a convenient method of estimating the probable severity and mortality of the disease in a majority of instances. Another criterion of the severity of tetanus is afforded by the extent and rate of development of the symptoms after the appearance of first stiffness of muscles, but this evidence is obviously not available at the onset of the disease.

In experimental tetanus produced by the injection of known amounts of tetanus toxin, the incubation period, rapidity of development of symptoms, elapsed time till death, and the mortality are direct functions of the size of the dose. The site of injection also is important. In tetanus developing after wounds the problem is

\footnotetext{
* Received for publication June 27. 1914.
} 
more complicated because the toxin is not received all at once, but is absorbed gradually as fast as produced. The rate of production depends in turn both on the amount of organisms introduced and on whether they find favorable or unfavorable conditions of growth. Conditions of growth may be favorable at once after the receipt of the wound, as in a deep puncture, or extensive laceration, or multiplication of the organisms may begin only after several days or weeks have elapced.

In the majority of cases, the incubation period expresses with a fair degree of accuracy the combination of these factors, although not infrequently some one element such as conditions in the wound, extent of surface injured, or amount of infection introduced may

TABLE 2

Mortality of Tetanus in Denmark

Cases Treated Without Serum (Permin and Faber)

\begin{tabular}{|c|c|c|c|}
\hline Incubation & Lived & Died & $\begin{array}{l}\text { Mortality, } \\
\text { Per Cent }\end{array}$ \\
\hline $\begin{array}{l}10 \text { days and less } \ldots \ldots \ldots \ldots \ldots \ldots \\
\text { Over } 10 \text { days } \ldots \ldots \ldots \ldots \ldots \ldots \ldots \\
\text { Unknown } \ldots \ldots \ldots \ldots \ldots \ldots \ldots\end{array}$ & $\begin{array}{r}5 \\
17 \\
20\end{array}$ & $\begin{array}{l}89 \\
40 \\
28\end{array}$ & $\begin{array}{l}94.7 \\
70.2 \\
58.3\end{array}$ \\
\hline Totals $\ldots \ldots \ldots \ldots \ldots \ldots$ & 42 & 157 & 78.9 \\
\hline \multicolumn{4}{|c|}{ Cases Treated with Serum (Permin) } \\
\hline Incubation & Lived & Died & $\begin{array}{l}\text { Mortality, } \\
\text { Per Cent }\end{array}$ \\
\hline $\begin{array}{l}10 \text { days and less } \ldots \ldots \ldots \ldots \ldots \ldots \ldots \\
\text { Over } 10 \text { days } \ldots \ldots \ldots \ldots \ldots \ldots \ldots \ldots \\
\text { Unknown } \quad \ldots \ldots \ldots \ldots \ldots \ldots \ldots\end{array}$ & $\begin{array}{l}25 \\
34 \\
21\end{array}$ & $\begin{array}{l}67 \\
23 \\
19\end{array}$ & $\begin{array}{l}72.8 \\
40.4 \\
47.5\end{array}$ \\
\hline 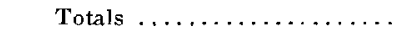 & 80 & 109 & 57.7 \\
\hline
\end{tabular}

vary from the usual to such an extent that symptoms appear four or five days after an injury, but develop slowly, so that the course of the disease is relatively mild, or, on the other hand, the production of tetanospasmin may be delayed for a number of days, and then proceed rapidly so that a fulminant disease develops after a long incubation period. If toxin is produced slowly in small amounts, time is afforded for the production of antitoxin by the host, and this probably has a part in the spontaneous recovery from the disease.

The evaluation of antitetanic serum in developed tetanus, a disease which presents so many variable factors influencing the prognosis, is a matter of considerable difficulty, and many experienced 
clinicians have doubted whether the results obtained from its use have been any better than those from symptomatic treatment. A study of the statistics of mortality of many hospitals shows that too often this skepticism has been well founded. Opposed to this pessimistic view are the reports of a number of small groups of carefully observed cases, such as those of Ashhurst and John in which the evidence seems strong that antitoxin deserved large credit for the recovery of some of the patients.

Permin ${ }^{1}$ has collected statistics in Denmark of the mortality of tetanus treated with and without serum and finds a mortality of 78.9 percent in 199 cases treated without serum, as compared with a mortality of 57.7 percent in 189 cases receiving serum.

TABLE 3

Cases Treated with Serum

\begin{tabular}{|c|c|c|c|c|}
\hline Incubation & $\begin{array}{l}\text { Total } \\
\text { Cases }\end{array}$ & Died & Recovered & $\begin{array}{l}\text { Mortality, } \\
\text { Per Cent }\end{array}$ \\
\hline 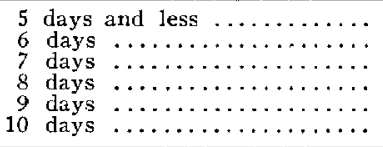 & $\begin{array}{l}38 \\
13 \\
21 \\
17 \\
24 \\
13\end{array}$ & $\begin{array}{r}27 \\
15 \\
16 \\
14 \\
17 \\
7\end{array}$ & $\begin{array}{r}11 \\
3 \\
5 \\
3 \\
7 \\
6\end{array}$ & $\begin{array}{l}\cdots \cdots \\
\cdots \cdots \\
\cdots \cdots \\
\cdots \cdots \\
\cdots \cdots\end{array}$ \\
\hline & 131 & 96 & 35 & 73.28 \\
\hline 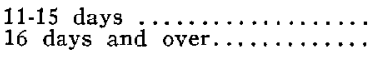 & $\begin{array}{l}47 \\
22 \\
69\end{array}$ & $\begin{array}{r}22 \\
6 \\
28\end{array}$ & $\begin{array}{l}25 \\
16 \\
41\end{array}$ & 40.57 \\
\hline $\begin{array}{l}\text { Incubation known } \ldots \ldots \ldots \ldots \ldots \\
\text { Incubation unknown } \ldots \ldots \ldots \ldots\end{array}$ & $\begin{array}{r}200 \\
25\end{array}$ & $\begin{array}{r}124 \\
1 j\end{array}$ & $\begin{array}{l}76 \\
10\end{array}$ & $\begin{array}{l}62.00 \\
60.00\end{array}$ \\
\hline Total cases $\ldots \ldots \ldots \ldots \ldots$ & 225 & 139 & 86 & 61.77 \\
\hline
\end{tabular}

Cases without Serum

\begin{tabular}{|c|c|c|c|c|}
\hline $\begin{array}{l}10 \text { days and less } \ldots \ldots \ldots \ldots \ldots \ldots \\
\text { Over } 10 \text { days } \ldots \ldots \ldots \ldots \ldots \ldots \ldots \\
\text { Unknown } \ldots \ldots \ldots \ldots \ldots \ldots \ldots\end{array}$ & $\begin{array}{r}12 \\
4 \\
5\end{array}$ & $\begin{array}{r}11 \\
2 \\
5\end{array}$ & $\begin{array}{l}1 \\
2 \\
0\end{array}$ & $\begin{array}{l}\cdots \\
\cdots \\
\cdots\end{array}$ \\
\hline Total $\ldots \ldots \ldots \ldots \ldots \ldots$ & 21 & 18 & 3 & 85.7 \\
\hline
\end{tabular}

The collection of the cases* of tetanus here analyzed was undertaken with the object of ascertaining in the first place what results

1. Mitt. a. d. Grenzgeb. d. Med, u. Chir, 1913, 27, p. 1

* All cases reported by any one observer are included in so far as the completeness of the data permit. The data of 80 cases were obtained by me directly from hospital records. About 20 cases occurred in the private practice of physicians. The remainder were treated in hospitals, for the most part large metropolitan-including Bellevue, Massachusetts General, Boston City, Buffilo General, Philadelphia General, Royal Victoria and Cook County, Wesley, Presbyterian and Michael Reese. To those who have kindly assisted in the collection of cases my best thanks are extended. I am especially indebted to Drs. O. Berghausen, Cincinnati; R. J. Carlisle, New York; Russell S. Fowler, Brooklyn; C. D. Fox, Philadelphia; F. S. Graves, Boston; G. W. Green, Chicago; H. C. Marble; A. C. Morgan, Philadelphia; John McCrae, Montreal; E. R. McGuire, Buffalo; J. J. Toland, Frankford, Pa.; Frank Vander Bogert, Schenectady; H. B. Wadsworth, Washington, Ind., and to others who supplied data of stmaller numbers of cases. 
are being obtained in this country with antitetanic serum in the treatment of tetanus (during the period 1907 to 1913), and in the second place, whether the failures in some cases may not be ascribed to the faulty and insufficient method of giving the serum. Statistical studies of cases collected from the literature are necessarily subject to error, and particularly in tetanus, such tabulations have led to conclusions favorable to serum treatment to a degree unwarranted by the actual facts.

With one or two possible exceptions, none of the cases in this series have been reported, and all were obtained by personal correspondence from hospital or private records. In all, this collection includes 225 cases treated with antitetanic serum, and 21 cases which received no serum.

Table 3 summarizes the mortality of the several classes of cases. The mortality of all cases receiving serum is 61.77 percent; in 21 cases without serum the mortality is 85.7 percent. The number of cases in this latter group is, of course, too small to establish a mortality for tetanus, but it agrees with the generally accepted figures of many writers on tetanus, 78 to 89 percent. It appears therefore that the mortality of cases in this series is about 20 percent lower in cases receiving serum than in those treated without serum. A further analysis of the cases with respect to the size of the dose, method of giving the serum, and duration of symptoms before the serum was given suggests the reasons for failure in some cases.

\section{DISTRIBUTION OF TOXIN IN TETANUS}

In the average patient suffering from tetanus in whom symptoms have just appeared the following conditions are present. Some of the toxin has already reached the central nervous system, and trismus or other evidence of tonic spasm suggests the diagnosis; another portion of toxin is ascending centralward in the nerves supplying the infected extremity; a still larger amount of toxin is present in the blood and is being taken up and is traveling centralward along the other nerves of the body. Some of these patients have already received in the peripheral and central nervous system a fatal dose of toxin when they are first seen, and will die no matter what is done. However, patients apparently hopeless, in whom convulsions have already begun, may recover, and since at the present time there seems 
to be no criterion by which we may be sure that the fatal dose has already reached the central nervous system, all cases should receive energetic treatment.

The necessity for haste is evident. The toxin still free in the blood must be neutralized as quickly as possible, and for this purpose the intravenous injection of serum is advisable. Next in rapidity of absorption is the intramuscular route, which should be employed if for any reason the intravenous method cannot be used. Antitoxin given subcutaneously reaches the maximum concentration in the blood only toward the end of the second twenty-four-hour period after

TABLE 4

Results with Respect to Time when Serum was Given and Size of Dose in First Twenty-four Hours of TrEatMent*

\begin{tabular}{|c|c|c|c|c|c|c|}
\hline \multirow[b]{2}{*}{ Incubation } & \multicolumn{2}{|c|}{ Large Döses } & \multicolumn{2}{|c|}{ Small Doses } & \multicolumn{2}{|c|}{ Mortality } \\
\hline & Died & Recovered & Died & Recovered & Large Dose & Small D. \\
\hline $\begin{array}{l}\text { A. Cases receiv } \\
10 \text { days and less } \\
\text { Over } 10 \text { days... }\end{array}$ & $\begin{array}{l}\text { ing first } \\
41 \\
11\end{array}$ & $\begin{array}{c}\text { serum with } \\
13 \\
15\end{array}$ & $\begin{array}{c}\text { in } 24 \text { hour } \\
21 \\
6\end{array}$ & $\begin{array}{c}\text { of first } \\
3 \\
3\end{array}$ & $\begin{array}{c}\text { symptoms: } \\
75.9 \\
42.3\end{array}$ & $\begin{array}{l}87.5 \\
66.6\end{array}$ \\
\hline $\begin{array}{l}\text { B. Cases receiv } \\
10 \text { days and less } \\
\text { Over } 10 \text {.lays. }\end{array}$ & $\underset{11}{52}$ & $\stackrel{28}{\substack{9 \\
8}}$ in & $\begin{array}{c}27 \\
\text { second } 24 \\
6 \\
1\end{array}$ & $\begin{array}{c}6 \\
\text { hours after } \\
0 \\
0\end{array}$ & $\begin{array}{c}65.0 \\
\text { first symp } \\
55.0 \\
20.0\end{array}$ & $\begin{array}{c}81.8 \\
\text { toms: } \\
100.0 \\
\cdots\end{array}$ \\
\hline $\begin{array}{l}\text { C. Cases receiv } \\
10 \text { days and less } \\
\text { Over } 10 \text { days... }\end{array}$ & $\begin{array}{c}13 \\
\text { ing first } \\
10 \\
7\end{array}$ & $\begin{array}{c}17 \\
\text { serum over } \\
6 \\
10\end{array}$ & $\begin{array}{c}7 \\
48 \text { hours } \\
7 \\
1\end{array}$ & $\begin{array}{c}0 \\
\text { after first } \\
4 \\
5\end{array}$ & $\begin{array}{c}43.3 \\
\text { symptoms: } \\
62.5 \\
41.1\end{array}$ & $\begin{array}{r}100.0 \\
63.6 \\
16.6\end{array}$ \\
\hline \multirow[t]{2}{*}{$\begin{array}{l}\text { Grand Totals: } \\
10 \text { days and less } \\
\text { Over } 10 \text { days ... }\end{array}$} & $\begin{array}{l}17 \\
62 \\
20\end{array}$ & $\begin{array}{l}16 \\
28 \\
33\end{array}$ & $\begin{array}{r}8 \\
34 \\
8\end{array}$ & $\begin{array}{l}9 \\
7 \\
8\end{array}$ & $\begin{array}{l}51.5 \\
68.8 \\
37.7\end{array}$ & $\begin{array}{l}47.0 \\
82.9 \\
50.0\end{array}$ \\
\hline & 82 & 61 & 42 & 15 & 57.3 & 73.7 \\
\hline
\end{tabular}

* In this table a small dose $=3,000$ units o: less subcutaneously; a large dose $=$ over 3,000 subcutaneously or 3,000 or less intraspinally or intravenously.

injection. This delay in absorption may entail a lapse of time sufficient to allow the development of a fatal intoxication. It is true that in some cases the formation of the toxin may proceed slowly, so that the subcutaneous injection of antitoxin may prove life saving, but in the ordinary acute case a dose of 1,500 or 3,000 units given subcutaneously can be of little immediate value in neutralizing toxin in the blood and staying the course of the disease.

The importance of intraspinal injection of antitoxin as a means of dealing with toxin that has already reached the central nervous system has been recently emphasized by Park, who has shown that 
animals in which tetanus has already developed may be saved by antitoxin in adequate doses and that the results are better and smaller doses required when the antitoxin is given intraspinally than when other routes are employed. These experimental results, together with a number of favorable results in human tetanus, indicate that the intraspinal injection of antitoxin should be urged in all cases of tetanus.

The intraneural injection of antitoxin serves to neutralize that portion of toxin peripheral to the point of injection in the nerves supplying the infected extremity, but from what we know of the distribution of toxin in the body in human tetanus, the instances in which this method alone is life saving must be extremely rare.

In Table 4 the cases are divided into groups with respect to (1) the incubation period, (2) the time elapsing from the appearance of symptoms to the beginning of treatment, and (3) the amount and efficiency of method of injection of the antitoxin during the first twenty-four hours of treatment. This classification may be criticised as faulty in a number of particulars, but taking the cases in the aggregate, it offers a basis of comparison as accurate as can be obtained from the data available. A comparison of the mortalities of cases receiving large and small doses of antitoxin shows the importance of adequate dosage and proper method of injection. In acute tetanus a small dose of antitoxin given subcutaneously does very little good. The reduction of aggregate mortality over the mortality of untreated tetanus is apparently due to the favorable results obtained in the cases where larger doses were employed in an effcient manner.

Some comment is necessary on the relative mortalities of cases receiving large doses in the first and second twenty-four-hour periods. The lower mortality in the second group (B) is obviously due not to the postponement of treatment, but to the fact that a large number of cases of acute tetanus die within twenty-four to thirty-six hours after the appearance of symptoms. Such cases will necessarily appear for the most part in the first group (A) and the second group (B) will accordingly show a lower mortality, through this unavoidable element of selection. Likewise the third group (C) contains some cases with slower onset, milder course and correspondingly less grave prognosis, in which necessity for rapid neutralization of toxin is 
less urgent, and the difference between the results obtained by large and small doses of antitoxin disappears. It should be remembered, however, that these cases are distinguishable only after the termination of illness, and the fact that they occur should be given no weight in planning the treatment of the individual case. Every case of tetanus is extremely serious.

Perhaps the most serious criticism to be urged against this classification of cases is that the grouping of cases as to duration of symptoms prior to the giving of antitoxin into periods of twentyfour hours, does not take into account whether patients received

TABLE 5

Results with Respect to Time when Serum was Given and Total Amount* OF SERUM USED

\begin{tabular}{|c|c|c|c|c|c|c|}
\hline \multirow[b]{2}{*}{ Incubation } & \multicolumn{2}{|c|}{ Large Doses } & \multicolumn{2}{|c|}{ Small Doses } & \multicolumn{2}{|c|}{ Mortality Percent } \\
\hline & Died & Recovered & Died & Recovered & Large Dose & Small D. \\
\hline $\begin{array}{l}\text { A. Cases receiv } \\
10 \text { days and less } \\
\text { Over } 10 \text { days .. }\end{array}$ & $\begin{array}{c}\text { ing first } \\
35 \\
10 \\
\end{array}$ & $\begin{array}{c}\text { serum with } \\
14 \\
16 \\
\end{array}$ & $\begin{array}{c}\text { in } 24 \text { hours } \\
27 \\
7\end{array}$ & of first & $\begin{array}{c}\text { symptoms: } \\
71.4 \\
41.5\end{array}$ & $\begin{array}{l}93.1 \\
77.7\end{array}$ \\
\hline $\begin{array}{l}\text { B. Cases receiv } \\
10 \text { days and less } \\
\text { Over } 10 \text { days .. }\end{array}$ & $\begin{array}{c}45 \\
\text { ing first } \\
11 \\
2\end{array}$ & $\begin{array}{c}30 \\
\text { serum in } \\
9 \\
8\end{array}$ & $\begin{array}{c}34 \\
\text { second } 24 \\
6 \\
1\end{array}$ & $\begin{array}{c}4 \\
\text { hours after } \\
0 \\
0\end{array}$ & $\begin{array}{c}60.0 \\
\text { first } \\
55.0 \\
20.0\end{array}$ & $\begin{array}{c}89.4 \\
\text { symptoms : } \\
100.0 \\
\ldots\end{array}$ \\
\hline $\begin{array}{l}\text { C. Cases receiv } \\
10 \text { days and less } \\
\text { Over } 10 \text { days } .\end{array}$ & $\begin{array}{c}13 \\
\text { ing first } \\
6 \\
4\end{array}$ & $\begin{array}{c}17 \\
\text { serum over } \\
7 \\
9\end{array}$ & $\begin{array}{c}7 \\
48 \text { houts } \\
11 \\
4\end{array}$ & $\begin{array}{c}0 \\
\text { after first } \\
3 \\
6 \\
\end{array}$ & $\begin{array}{c}43.3 \\
\text { symptcms: } \\
46.1 \\
30.7\end{array}$ & $\begin{array}{r}100.0 \\
78.5 \\
40.0\end{array}$ \\
\hline \multirow{3}{*}{$\begin{array}{l}\text { Grand Totals: } \\
10 \text { days and less } \\
\text { Over } 10 \text { days .. }\end{array}$} & 10 & 16 & 15 & 9 & 38.4 & 62.5 \\
\hline & $\begin{array}{l}52 \\
16 \\
\end{array}$ & $\begin{array}{l}30 \\
33\end{array}$ & $\begin{array}{l}44 \\
12 \\
\end{array}$ & $\begin{array}{l}5 \\
8 \\
\end{array}$ & $\begin{array}{l}63.4 \\
32.6 \\
\end{array}$ & $\begin{array}{l}89.7 \\
60.0\end{array}$ \\
\hline & 68 & 63 & 56 & 13 & 51.9 & 81.1 \\
\hline
\end{tabular}

* A small dose $=10,000$ units or less subcutaneous. A large dose $=$ over 10,000 sub cutaneous or less than 10,000 intraspinal or intravenous.

first treatment at the beginning or the end of the first twenty-four hour period, i. e., whether antitoxin was administered immediately after symptoms appeared or whether twenty-four hours elapsed before treatment was begun. As pointed out by Park, twenty-four hours is a long time in tetanus. The data available in the cases in this series did not allow of a division of time smaller than twenty-four-hour periods. With the more general appreciation of the necessity for treatment immediately after the appearance of symptoms, more accurate data, which should be stated in hours rather than days, will be available for statistical study. 
In Table 5 the results of treatment with antitetanic serum are tabulated with the same grouping as in Table 4, but with respect to the total amount of serum used in each case. In this tabulation a small dose is defined as 10,000 units or less, given subcutaneously, and a large dose as more than 10,000 units subcutaneously or less than 10,000 units, if given intravenously or intraspinally. Most of the cases receiving small doses were given 1,500 or 3,000 units per day, subcutaneously, an amount obviously too small to be of service in an acute case; while most of the cases in the class receiving large doses were given considerably more than 10,000 units subcutaneously, or less amounts intraspinally or intravenously. This purely arbitrary division affords a basis for the comparison of the effects of dosage in the series under discussion, but is not intended as a guide for the treatment of the individual case. It should be noted that even in those cases receiving relatively large doses subcutaneously, the distribution of dosage through the first twenty-four-hour period was such that the maximum concentration of antitoxin could not have been attained until well into the following twenty-four hours.

TABLE 6

Mortality of Tetanus Treated by Intraspinal and by Intravenues Injections of Antitoxin, Without Regard to the Time Treatment was Begun

\begin{tabular}{l|c|c|c|c|c|c}
\hline & \multicolumn{3}{|c|}{ Intraspinal } & \multicolumn{3}{|c}{ Intravenous } \\
\hline & Cases & Died & $\begin{array}{l}\text { Mortality, } \\
\text { Per Cent }\end{array}$ & Cases & Died & $\begin{array}{c}\text { Mortality, } \\
\text { Per Cent }\end{array}$ \\
\hline Acute $\ldots \ldots \ldots$ & 16 & 13 & 81.2 & 11 & 8 & $\ldots$ \\
Chronic $\ldots \ldots \ldots$ & 17 & 5 & 29.4 & 5 & 2 & $\ldots$ \\
\hline Unknown $\ldots \ldots$ & 4 & 3 & $\cdots$ & 4 & 3 & $\ldots$ \\
\hline & 37 & 21 & 56.7 & 20 & 13 & 65.0 \\
\hline
\end{tabular}

The method of grouping is subject to the same criticisms as that of Table 4, and in addition a further error is thavoidably introduced in that those cases which died early in the disease had less opportunity to receive large doses of antitoxin, and consequently increase the percentage of mortality of the cases receiving small doses. This accentuates unduly, the difference between results from large and small doses.

In general the results with large doses are considerably better than those with small doses, although as indicated above, the actual difference is probably not as great as is indicated by the percentages. 
RESULTS WITII INTRAVENOUS AND INTRASPINAL INJECTIONS

A limited number of observations on the effects of intravenous and intraspinal methods of injection are available in this series.

Twenty patients, of whom 11 were acute, 5 chronic, and 4 unknown incubation, received intravenous injections of serum either alone or in combination with other methods of injection. The collective mortality of these was 65 percent. Of those who died, however, treatment was begun within eight hours in 1, within twenty-four houts in 5 , on the third day in 2 and on the fourth day of symptoms, or later, in 3 . In 2 the duration of symptoms before treatment was not noted.

Of 37 patients who received antitetanic serum intraspinally either alone or in combination with other methods of injection, 16 were acute, 17 chronic and in 4 the incubation period was unknown. The collective mortality was 56.7 percent. Of those who died 5 received antitoxin within twenty-four hours after the appearance of symptoms, 5 received first treatment on the second day of symptoms, 4 on the third day, 2 on the fifth day or later, and in 3 the duration of symptoms before treatment was not noted.

The delay of treatment until the second or third day of symptoms, and the small doses (1,500 to 3,000 units) which a number of these patients received, go far toward explaining the failure of these methods to reduce the death-rate in this series below 50 percent. The unfortunate fact that often patients do not apply for treatment until the second or even the third day of symptoms can not be used as an argument against a method of treatment which offers a reasonable hope of success if instituted early in the disease.

\section{MAGNESIUM SULPHATE}

Magnesium sulphate was given intraspinally in eighteen cases which also received serum. Four cases, two acute and two chronic, recovered, giving a mortality for the group of 77 percent. In two cases death occurred shortly after the injection, with symptoms of respiratory paralysis.

\section{SUMMARY}

From these statistics it appears that the mortality of tetanus treated by tetanus antitoxin is about 20 percent lower than the average mortality of tetanus treated without serum. 
The mortality of cases treated by efficient methods and adequate dose is considerably lower than that of cases receiving small doses subcutaneously.

\section{SUGGESTIONS FOR THE TREATMENT OF TETANUS}

The prophylactic value of tetanus antitoxin is established, and needs no argument for its support. That tetanus antitoxin properly used may save the life of a patient in whom tetanus has already developed should be more generally recognized, and the treatment employed in every case at the earliest moment possible. Every hour lost before the giving of the antitoxin decreases the chance of saving life. By no means every case will recover but certainly more can be saved than have been in the past five years, and there is every reason to anticipate that with a proper use of antitoxin a mortality considerably lower than the present will be obtained.

It is important that the full effect of the antitoxin should be obtained immediately and this may be accomplished by giving, as outlined by Park, 3,000 to 5,000 units intraspinally and 10,000 to 20,000 units intravenously at the earliest possible moment after symptoms of tetanus appear. On the following day the intraspinal injection may be repeated. The blood remains strongly antitoxic for several days. On the fourth or fifth day 10,000 units should be given subcutaneously to maintain the antitoxin content of the blood.

It is doubtful whether the enormous doses given in some cases over periods of many days are any more effective than the more limited dosage outlined above by which the maximum concentration of antitoxin in the body is attained at once. If only a small amount of antitoxin ( 3,000 to 5,000 units) is available it should be given intraspinally. Intraspinal and intravenous injections should be given with all the precautions usually employed for these methods.

The danger of immediate anaphylactic shock following intravenous and intraspinal injection of tetanus antitoxin has been suggested as an objection to these methods of giving the serum, but when we consider the relative rarity of fatal instances of such complications in the treatment of diphtheria either by intravenous or subcutaneous injections, and the grave prognosis in untreated tetanus, it is evident that the remote possibility of fatal serum disease should be given little weight in determining treatment.

This tse of antitoxin in no respect replaces other necessary recognized non-specific methods of treatment in tetanus. Surgical treat- 
ment of the site of infection should be instituted at once. The patient should be placed at rest in bed in a quiet darkened room, and should receive sufficient sedatives to control convulsions, together with adequate supply of fluid nourishment, and attention to the elimination by kidney and bowel. The necessity for large and continued doses of sedatives such as chloral or chlorbutanol should not blind the physician to the possible danger of giving an overdose. The condition of the patient should be carefully watched, and a revision of the standing orders for sedatives made whenever symptoms suggest the decrease or increase of dose. 